Article (refereed)

Matejko, Malgorzata; Dore, Antony J.; Hall, Jane; Dore, Christopher J.; Blas, Marek; Kryza, Maciej; Smith, Rognvald; Fowler, David. 2009 The influence of long term trends in pollutant emissions on deposition of sulphur and nitrogen and exceedance of critical loads in the United Kingdom.

Environmental Science and Policy, 12. 882-896.

10.1016/j.envsci.2009.08.005

\title{
(C) 2009 Elsevier Ltd
}

This version available http://nora.nerc.ac.uk/9364/

NERC has developed NORA to enable users to access research outputs wholly or partially funded by NERC. Copyright and other rights for material on this site are retained by the authors and/or other rights owners. Users should read the terms and conditions of use of this material at http://nora.nerc.ac.uk/policies.html\#access

This document is the author's final manuscript version of the journal article, incorporating any revisions agreed during the peer review process. Some differences between this and the publisher's version remain. You are advised to consult the publisher's version if you wish to cite from this article.

www.sciencedirect.com 
Published in: ENVIRONMENTAL SCIENCE \& POLICY (2009)

\title{
The influence of long term trends in pollutant emissions on deposition of sulphur and nitrogen and exceedance of critical loads in the United Kingdom
}

\author{
Authors: Malgorzata Matejko ${ }^{a^{*}}$, Anthony. J. Dore ${ }^{\mathrm{b}}$, Jane Hall ${ }^{\mathrm{c}}$, Christopher. J. Dore ${ }^{\mathrm{d}}$, \\ Marek Błaśa ${ }^{a}$ Maciej Kryza ${ }^{a}$, Rognvald Smith ${ }^{b}$, and David Fowler \\ ${ }^{\text {a }}$ Department of Meteorology and Climatology, University of Wrocław, Kosiby 8, Wrocław 51-670, Poland \\ ${ }^{\mathrm{b}}$ Centre for Ecology and Hydrology, Penicuik, Midlothian EH26 9HF, UK \\ ${ }^{\mathrm{c}}$ Centre for Ecology and Hydrology, Environment Centre Wales, \\ Deiniol Road, Bangor, Gwynedd, LL57 2UW, UK \\ d AETHER Ltd, 99 Milton Park, Abingdon OX14 4RY, UK \\ *) corresponding author: \\ Małgorzata Matejko, email: matejko@meteo.uni.wroc.pl \\ Tel. +48 71-348-54-41; Fax. +48 71-372-94-98
}

\begin{abstract}
In the United Kingdom, as with other European countries, land-based emissions of $\mathrm{NO}_{\mathrm{X}}$ and $\mathrm{SO}_{2}$ have fallen significantly over the last few decades. $\mathrm{SO}_{2}$ emissions fell from a peak of $3185 \mathrm{Gg} \mathrm{S}$ in 1970 to $344 \mathrm{Gg} \mathrm{S}$ in 2005 and are forecast by business-as-usual emissions scenarios to fall to $172 \mathrm{Gg}$ by 2020 . $\mathrm{NO}_{\mathrm{X}}$ emissions were at a maximum of $951 \mathrm{Gg} \mathrm{N}$ in 1970 and fell to 378 by 2005 with a further decrease to $243 \mathrm{Gg} \mathrm{N}$ forecast by 2020. These large changes in emissions have not been matched by emissions changes for $\mathrm{NH}_{3} \mathrm{which}$ decreased from $315 \mathrm{Gg} \mathrm{N}$ in 1990 to 259 in 2005 and are forecast to fall to 222 by 2020. The Fine Resolution Atmospheric Multi-pollutant Exchange model (FRAME) has been applied to model the spatial distribution of sulphur and nitrogen deposition over the United Kingdom during a 15 year time period (1990-2005) and compared with measured deposition of sulphate, nitrate and ammonium from the national monitoring network. Wet deposition of nitrogen and sulphur was found to decrease more slowly than the emissions reductions rate. This is attributed to a number of factors including increases in emissions from international shipping and changing rates of atmospheric oxidation. The modelled time series was extended to a 50 year period from 1970 to 2020. The modelled deposition of $\mathrm{SO}_{\mathrm{x}}, \mathrm{NO}_{\mathrm{y}}$ and $\mathrm{NH}_{\mathrm{x}}$ to the $\mathrm{UK}$ was found to fall by $87 \%, 52 \%$ and $25 \%$ during this period. The percentage of the United Kingdom surface area for which critical loads are exceeded is estimated to fall from $85 \%$ in 1970 to $37 \%$ in 2020 for acidic deposition and from $73 \%$ to $49 \%$ for nutrient nitrogen deposition. The significant reduction in land emissions of $\mathrm{SO}_{2}$ and $\mathrm{NO}_{\mathrm{X}}$ focuses further attention in controlling emissions from international shipping. Future policies to control emissions of ammonia from agriculture will be required to effect further significant reductions in nitrogen deposition.
\end{abstract}

Keywords: acid deposition, critical loads, FRAME, sulphur, nitrogen 


\section{Introduction}

Acid deposition, originating mainly from man made emissions of $\mathrm{SO}_{2}, \mathrm{NO}_{\mathrm{x}}$ and $\mathrm{NH}_{3}$ has had significant ecological and economic consequences, especially during the last two decades of the 20th century, affecting forests, soil and freshwater ecosystems in large areas of Europe (Posch et al., 1997; EEA, 1998; Berge et al., 1999; Davies et al., 2004; Vuorenmaa, 2004; Błaś et al., 2008; Fagerli et al., 2008). The total area affected by exceedance of acidifying sulphur and nitrogen on a European scale was about $20 \%$ in the mid eighties (Posch et al., 1997; Berge et al., 1999; Mill et al., 2003).

In many countries depositions and concentrations to a large extent originate from sources outside the countries themselves and it is necessary to assess the changes on a larger scale, taking into account the trans-boundary fluxes (Fowler et al., 2007). Hence the problems of acidification have been addressed internationally by the 1979 Geneva Convention on Long Range Trans-boundary Air Pollution (CLRTAP) and two protocols targeting sulphur emission reductions have been signed in Europe (Berge et al., 1999). As a result of international pollutant abatement policy and structural changes in industrial sector, substantial reductions in gaseous emissions have been observed, with $\mathrm{SO}_{2}$ being reduced most significantly. Land based sulphur emissions from 1970 to 2005 declined by between 90 and $70 \%$ depending on the region of Europe (Fowler et al., 2007). Larger reductions were found in the area of the former Soviet Union and western Europe than in central eastern Europe (Berge et al., 1999; Mitosek et al., 2004). For oxidized and reduced nitrogen the overall European reductions from 1980 to 2003 were between 20 and 50\%. Both oxidized and reduced nitrogen emissions fell more in eastern Europe than in western Europe (Fowler et al., 2005; Fagerli et al., 2008).

Air pollution emissions of $\mathrm{SO}_{2}$ and $\mathrm{NO}_{\mathrm{x}}$ have decreased in the UK significantly during recent decades due to active control measures and economic changes. There were large changes in the power industry sector where coal was changed for gas and abatement facilities were 
installed. The deposition of sulphur and nitrogen in the UK has declined since the peak in emission in 1970 by $50 \%$ and 16\%, respectively (NEGTAP, 2001; Fowler et al., 2005). Emissions of $\mathrm{NH}_{3}$ have changed little since the peak emissions in the mid 1980's, but a decline of $12 \%$ relative to 1990 is expected by 2010 (EMEP, 2006).

Here attention is focused on non-linearities in the relationship between the emission and deposition changes. The national reduction in deposition is clearly smaller than the reduction in emission and it also leads to slower reductions in critical loads exceedance in remote areas than may be expected (NEGTAP, 2001; Irwin et al., 2002; Fournier et al., 2004). Non-linearities for sulphur emission-deposition patterns in the UK can be explained by increases in emissions from international shipping, changes in atmospheric oxidation rates and complex interactions between the different pollutants which can influence deposition rates (i.e. the co-deposition of $\mathrm{NH}_{3}$ and $\mathrm{SO}_{2}$; Fowler et al., 2007). Mayerhofer et al. (2002) concluded that for regional air pollution the development of the air pollutant emissions is more important than the effect of climate change on the dispersion and chemical transformation of air pollutants. Fagerli and Aas (2008) investigated the role of sulphur in the emission-deposition relationship of oxidized and reduced nitrogen and to what extent the reductions of $\mathrm{SO}_{2}$ emissions have influenced the trends of the nitrogen compounds.

The UK Lagrangian trajectory models such as HARM (Metcalfe et al., 2001), TRACK (Lee et al., 2000) and FRAME (the Fine Resolution Atmospheric Multi-pollutants Exchange model; Singles et al., 1998) have been developed to asses acid deposition to sensitive areas. These models use a spatial emissions inventory and give deposition at grid squares throughout the $\mathrm{UK}$ at a $5 \mathrm{~km} \times 5 \mathrm{~km}$ resolution.

In this paper we consider recent trends in emissions of $\mathrm{SO}_{2}, \mathrm{NO}_{\mathrm{x}}$ and $\mathrm{NH}_{3}$ and compare the model with measurements from the UK national monitoring network for wet deposition of sulphate, nitrate and ammonium during the period 1990-2005. A longer time 
series covering a 50 year period from 1970, the earliest year for which a detailed emissions inventory for the UK is available, to year 2020, based on detailed emissions projections, is considered and an assessment of the associated changes in nitrogen and sulphur deposition and exceedance of acid and nitrogen critical loads for acid deposition and nutrient nitrogen deposition.

\section{Data \& methods}

\subsection{FRAME model description}

A detailed description of the Fine Resolution Atmospheric Multi-pollutant Exchange model is provided by Singles et al. (1998), Fournier et al. (2005) and Dore et al. (2007). FRAME is a statistical atmospheric transport model that can be used to estimate the spatial distribution of sulphur and nitrogen deposited to the United Kingdom. FRAME simulates the main atmospheric processes (emission, diffusion, chemical transformations and deposition) taking place in a column of air moving along straight-line trajectories following specified wind directions. The column is divided into 33 separate layers of varying thickness ranging from $1 \mathrm{~m}$ at the surface and increasing to $100 \mathrm{~m}$ at the top of the domain (ApSimon et al., 1994). Vertical mixing is described using K-theory eddy diffusivity and solved with a finite volume method (Vieno, 2005).

The FRAME domain covers the UK and the Republic of Ireland with a grid resolution of $5 \mathrm{~km} \times 5 \mathrm{~km}$ and grid dimension of $172 \times 244$. Input gas and aerosol concentrations at the edge of the model domain are calculated with FRAME-Europe, a large scale European version of FRAME-UK which runs on the EMEP grid at a $50 \mathrm{~km}$ resolution. Trajectories are advected across the domain, with different starting angles at a 1 degree resolution, using directionally dependent wind speed and wind frequency roses. The wind speed rose employed in FRAME uses radiosonde data (Dore et al., 2006) but the wind frequency rose is based on 
the Jenkinson objective classification of circulation type which has superseded the Lamb weather classification (Lamb, 1972; www.cru.uea.ac.uk/cru/data/lwt.htm).

As the air column moves along the trajectory, chemical interactions between ammonia, sulphur dioxide and nitrogen oxides take place. The chemical scheme applied in the model includes gas and aqueous phase reactions and is similar to that applied in the EMEP Lagrangian model (Barret and Seland, 1995). Dry deposition is calculated by determining a vegetation-dependent deposition velocity $\left(\mathrm{V}_{\mathrm{d}}\right)$ to each chemical species derived from a dry deposition model (Smith et al., 2000). The following land classes are considered: forest, grassland, moorland, arable, urban and water. Values of $\mathrm{V}_{\mathrm{d}}$ are calculated for each land use category using a canopy resistance model (Singles et al., 1998). Wet deposition is determined with scavenging coefficients and a constant drizzle approach. An increased washout rate is assumed over hill areas due to the seeder-feeder effect. It is assumed that the washout rate for the orographic component of rainfall is twice that used for the non-orographic components (Dore et al., 1992).

To take into account changes in chemical climate, the concentration ratio $\mathrm{SO}_{2}: \mathrm{NH}_{3}$ is used to calculate the canopy resistance for deposition of $\mathrm{SO}_{2}$. Long term measurements of the deposition velocity of $\mathrm{SO}_{2}$ at Auchencorth Moss in Scotland and Speulder Forest in the Netherlands show a generally increasing trend as the acidity of the environment has declined due to reductions in $\mathrm{SO}_{2}$ emissions during the last decade (Fowler et al, 2007).

A simple linear correlation is assumed in the FRAME:

$$
\mathrm{R}_{\mathrm{c}}=50 *\left(\left[\mathrm{SO}_{2}\right] /\left[\mathrm{NH}_{3}\right]\right)
$$

Where $\left[\mathrm{SO}_{2}\right]$ and $\left[\mathrm{NH}_{3}\right]$ are the concentrations of $\mathrm{SO}_{2}$ and $\mathrm{NH}_{3}$ in air by mass respectively The deposition velocity of $\mathrm{SO}_{2}$ was calculated according to the equation:

$$
\mathrm{V}_{\mathrm{d}}\left(\mathrm{SO}_{2}\right)=\left(\mathrm{R}_{\mathrm{a}}+\mathrm{R}_{\mathrm{b}}+\mathrm{R}_{\mathrm{c}}\right)^{-1}
$$


$\mathrm{R}_{\mathrm{a}}$ - aerodynamic resistance, due to turbulent diffusion of material to the roughness elements of the surface

$\mathrm{R}_{\mathrm{b}}$ - laminar boundary layer resistance, describes the transfer due to molecular diffusion through the quasi-laminar layer around the roughness elements

$\mathrm{R}_{\mathrm{c}}$ - surface resistance, describes the ability of the surface itself to capture airborne material and is dependant on the nature of the surface

The decrease of the $\left[\mathrm{SO}_{2}\right]:\left[\mathrm{NH}_{3}\right]$ ratio is responsible for the increase of the $\mathrm{SO}_{2}$ deposition velocity. Due to emissions reductions, the depletion of atmospheric oxidants became less of a controlling factor in determining the rate of conversion of pre-cursor gases to sulphate and nitrate aerosol (which make a major contribution to wet deposition).

\subsection{Meteorological model inputs (1990-2005)}

Precipitation data used in the modelling is generated by interpolation of measurements from the tipping bucket rain gauges gathered at the Meteorological Office national network on approximately 5000 stations. The data are in the form of annual rainfall fields for the UK and Ireland on a $5 \mathrm{~km} \times 5 \mathrm{~km}$ grid. The national mean annual precipitation was $1130 \mathrm{~mm}$ for the period 1990-2005 and ranged from $880 \mathrm{~mm}$ in 2003 to $1330 \mathrm{~mm}$ in 2000 . The years 1998 , 2000 and 2002 were wet years while 1996 and 2003 were dry, relative to the mean for the period.

A higher precipitation amount is noticed at the western coastal and at higher altitude sites. However, during the wet year (2000), areas of hilly regions with precipitation above $2000 \mathrm{~mm}$ year $^{-1}$ are considerably larger. The substantial enhancement in rainfall with altitude can be partially explained with the seeder-feeder enhancement mechanism, whereby rain falling from a higher level cloud (seeder cloud) layer passes through an orographically formed 
"cap cloud" (feeder cloud) over high terrain (Carruthers and Choularton 1983, Błaś et al., 1999). As it passes through the cap cloud, the rain scavenges cloud droplets, adding to the rainfall amount and ion content. The concentration is enhanced since cloud droplets are much smaller than rain drops and are thus far more concentrated for a given aerosol loading (e.g. Choularton et al. 1988, Dore et al. 1992, Inglis and Choularton 2000).

Wind direction frequency information was taken from the classification of LambJenkinson weather types (Lamb, 1972; Hulme \& Barrow, 1997). The classification consists of two parts: wind direction (N, NE, E, SE, S, SW, W, NW, N and unclassified) and circulation type (cyclonic, anti-cyclonic \& unclassified). In Fig. 1, three wind frequency roses are plotted: average for the period 1990-2005, and individual for 1996 and 2004.

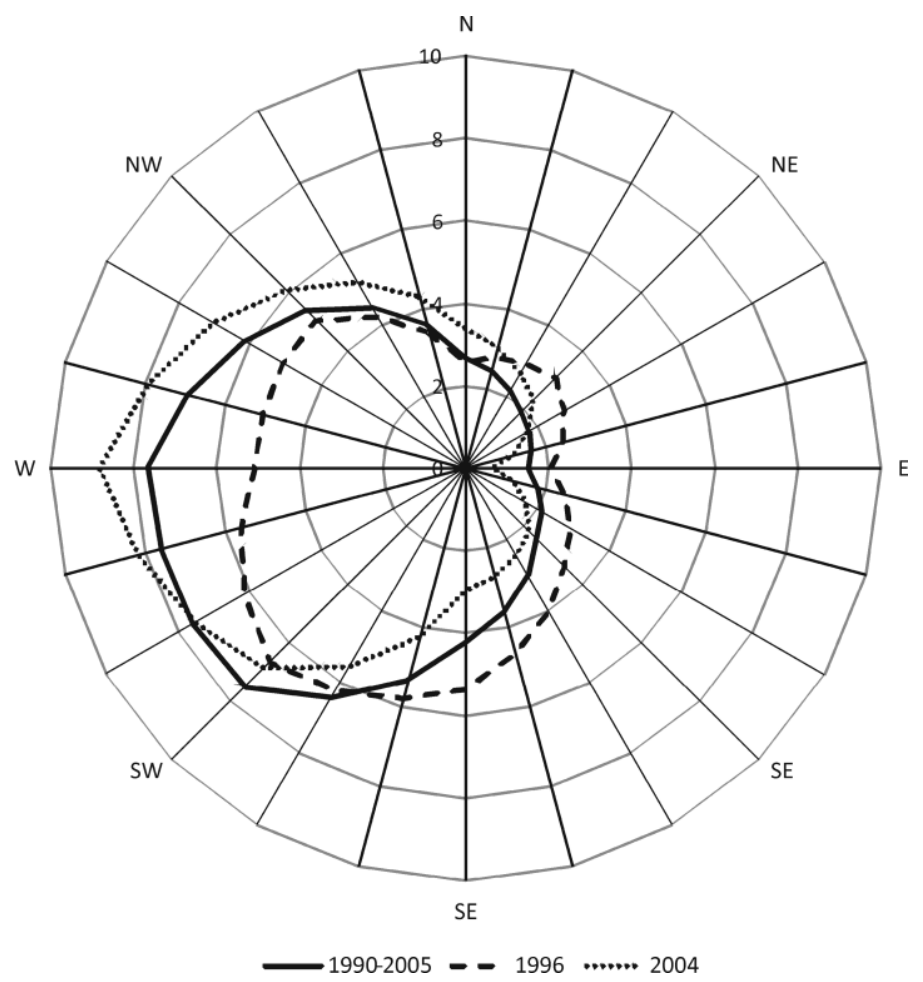

Fig. 1. The 1990-2005 average wind frequency rose compared to 1996 and 2004 wind frequency roses. Radial units are percent per $15^{\circ}$ direction band (\%)

The years 1996 and 2004 were selected for presentation because they are representative for low and high wind frequency from $\mathrm{E}+\mathrm{SE}+\mathrm{S}$ directions within the considered period, respectively. The average wind rose illustrates that predominant wind 
directions are from the SW-W. The individual wind roses show a greater incidence of easterlies in 1996 and westerlies in 2004.

To prepare the wind speed rose radiosonde data has been used. In order to sample data from different geographical locations, four stations were selected in the British Isles. The selection criteria for data were based upon: the existence of a complete ten year data set, Geographical representation of the northern, southern, western and eastern limits of the British Isles. These were: Camborne (south-west England); Hemsby (east coast of England); Stornoway (north-west Scotland) and Valentia (on the west coast of the Republic of Ireland). As suggested by Dore et al., 2006, one wind speed rose - a harmonic mean for the period has been used in the model.

\subsection{Emission inventory used in modelling}

In order to calculate past and future deposition of sulphur and nitrogen to the UK, it is necessary to generate historical and forecast emissions maps. Although some historical emissions maps are available (i.e. for the year 1990), much of these data are incompatible with more recent emissions data as they are gridded at a coarser resolution (10 km for 1990 and $1 \mathrm{~km}$ for 2005) and are lacking in separate information on point source emissions. In estimating the temporal trends in deposition to the UK, it is important for input emissions data for different years to be identically formatted otherwise artificial changes in modelled deposition may be generated. The background and point source emissions files for the year 2002 were taken to be the baseline year. The data for total emissions were used to scale emissions backwards in time and generate new emissions files for the years 1970, 1980, 19902001. Emissions from the National Atmospheric Emissions Inventory (NAEI, www.naei.org) were used for 2003, 2004 and 2005. Future emissions for the years 2010 and 2020 were obtained by scaling the 2005 emissions data forward in time. The future emissions projections for the UK for the years 2010 and 2020 were based on those from the Air Quality Strategy 
(Grice et al., 2005). Area emissions data were divided into eight different SNAP codes (Selected Nomenclature for Air Pollution). Year-dependent scaling factors were assigned to each SNAP emission sector. The UK NH 3 emissions for the years 1970 and 1980 were set at the 1990 level. Emissions from the Republic of Ireland are also included explicitly in the FRAME domain and these were scaled backwards in time in a similar manner to the UK emissions. Future emissions for the years 2010 and 2020 for the Republic of Ireland were set at the levels defined by the National Emissions Ceiling Directive (NECD). Emissions of $\mathrm{SO}_{2}$ and $\mathrm{NO}_{\mathrm{x}}$ from international shipping were also included in the domain. These were scaled forwards and backwards in time from the baseline year 2000 according to estimates from the NAEI. Globally, shipping emissions of $\mathrm{SO}_{2}$ are estimated to be increasing at a rate of between 2.5\% and $1.5 \%$ per year (Endressen et al., 2003; Corbett et al, 2003). Here we have adopted the figure of $2.5 \%$. Considerable uncertainty however remains both in the spatial distribution of shipping emissions and in their magnitude and regional rate of change. The emissions (ENTEC 2002) were gridded on the EMEP $50 \mathrm{~km}$ grid. Future work will focus on implementation of higher resolution shipping emissions data at a $5 \mathrm{~km}$ resolution in the model. The relative contribution of shipping emissions within the FRAME-UK domain to total sulphur and nitrogen deposition in the UK has increased from $5 \%$ to $23 \%$ and from $11 \%$ to $21 \%$ respectively over the period $1990-2005$. However the imposition of Annex VI of the MARPOL convention will restrict the sulphur content of bunker fuel to $0.1 \%$ in the North Sea resulting in major reductions in $\mathrm{SO}_{2}$ emissions by the year 2020 .

Future emissions were generated assuming that shipping emissions in the UK waters are compliant with the IMO directive to reduce the sulphur content of bunker fuel to $0.5 \%$ in the North Sea by the year 2020 as well as the gradual introduction of low NOx emitting engines. The contribution of shipping emissions to sulphur deposition in the UK is discussed in detail in Dore et al. (2007). 


\subsection{Model evaluation}

As the aim of the paper is related with the deposition trends, the model results are evaluated in two ways. First, the results are compared with the available measurements. Second, FRAME modelled data are compared against the CBED (Concentration Based Estimated Deposition; Smith et al. $(2000,2001))$ wet deposition data which is generated from measurements from the national monitoring networks of gas concentrations in air and ion concentrations in precipitation. CBED dry and wet deposition forms the official UK data set for estimation of exceedance of critical loads for acid deposition and nitrogen deposition. Unfortunately, long term dry deposition is only measured directly at a very few sites in the UK, which means a direct model-measurement comparison of dry deposition is not feasible. Modelled gas concentrations $\left(\mathrm{SO}_{2}, \mathrm{NO}_{2}, \mathrm{NH}_{3}, \mathrm{HNO}_{3}\right)$ have been compared with measurements in Dore et al. (2006) and were shown to give satisfactory agreement. Continuous monitoring of these compounds was started in the late 1990s and forms a shorter data series than that for wet deposition. In this paper we focus on comparison with measurements of wet deposition during the period 1990-2005. For this period, the wet deposition network contains 32 stations, which are located away from major local sources of contamination and are in rural locations.

Two error measures are used for the evaluation of the FRAME modelled wet deposition: mean bias (MB) and mean absolute error (MAE). MB is commonly used to describe the general over or underestimation by the model, while MAE gives information on average error (Chang and Hanna, 2004; Yu et al., 2006). The MB and MAE statistics are supported by the correlation coefficient $(\mathrm{R})$ and regression analysis between modelled and measured wet deposition, which are performed for each year of the 1990 - 2005 period.

\section{Results and discussion}


Modelled wet deposition results were compared against measured values. All the correlations are statistically significant (p-value $<0.05)$ as well as slopes and intercept value for linear regression are reasonable. The results for $\mathrm{SO}_{4}{ }^{2-}$, give a correlation coefficient in the range of 0.60 to 0.83 . Similar correlation coefficients are obtained for $\mathrm{NH}_{4}{ }^{+}$and $\mathrm{NO}_{3}{ }^{-}$but with better results for intercept values.

For $\mathrm{SO}_{4}{ }^{2-}$ and $\mathrm{NO}_{3}{ }^{-}$Mean Bias and Mean Absolute Error are higher at the beginning of the analyzed period and after these values clearly go down. MB goes down from 4.16 in 1990 to 0.70 in 2004 for $\mathrm{SO}_{4}{ }^{2-}$, from 1.08 to $(-0.43)$ for $\mathrm{NO}_{3}{ }^{-}$, and $\mathrm{MAE}$ from 5.20 to $1.8,1.62$ to 1.54, respectively. The improvement of these statistics during the second part of the period can be attributed to the improvement in emissions inventory. In case of $\mathrm{NH}_{4}{ }^{+}$, the downward trend is not clear, despite the fact that MB is the smallest for year 2005. MAE amounts to about $1.80-2.00$ and $\mathrm{MB}$ is close to 1 .

Fig. 2(a)-(c) illustrate the correlation with measurements of modelled $\mathrm{NH}_{4}{ }^{+}, \mathrm{NO}_{3}{ }^{-}$, $\mathrm{SO}_{4}{ }^{2-}$ wet deposition for 2005. For $\mathrm{SO}_{4}{ }^{2-}$ the model performs particularly well against measurements for low deposition and somewhat overestimates higher values (which usually occurs in hilly regions). For $\mathrm{NO}_{3}{ }^{-}$and $\mathrm{NH}_{4}{ }^{+}$lower deposition is also represented better, with the number of points above/below 2:1 and 1:2 reference lines being lower than for higher deposition values, which appears both as overestimations and underestimations.

Overestimation usually occurs in hilly regions and might be due to the simple parameterization of the seeder-feeder effects, which is currently based on the long term precipitation data. For mountainous stations accurate estimates of precipitation amount are especially crucial for determination of pollutant deposition. Underestimations are especially evident for stations situated close to coastal zone. This could be a consequence of a limitation of the FRAME-Europe model which is used to generate conditions at the edge of FRAME domain by considering straight-line trajectories. This approach does not allow air from 
emission sources to be trapped in cyclonic conditions and so to come back to the precipitation part of the depression (Fournier et al., 2004).
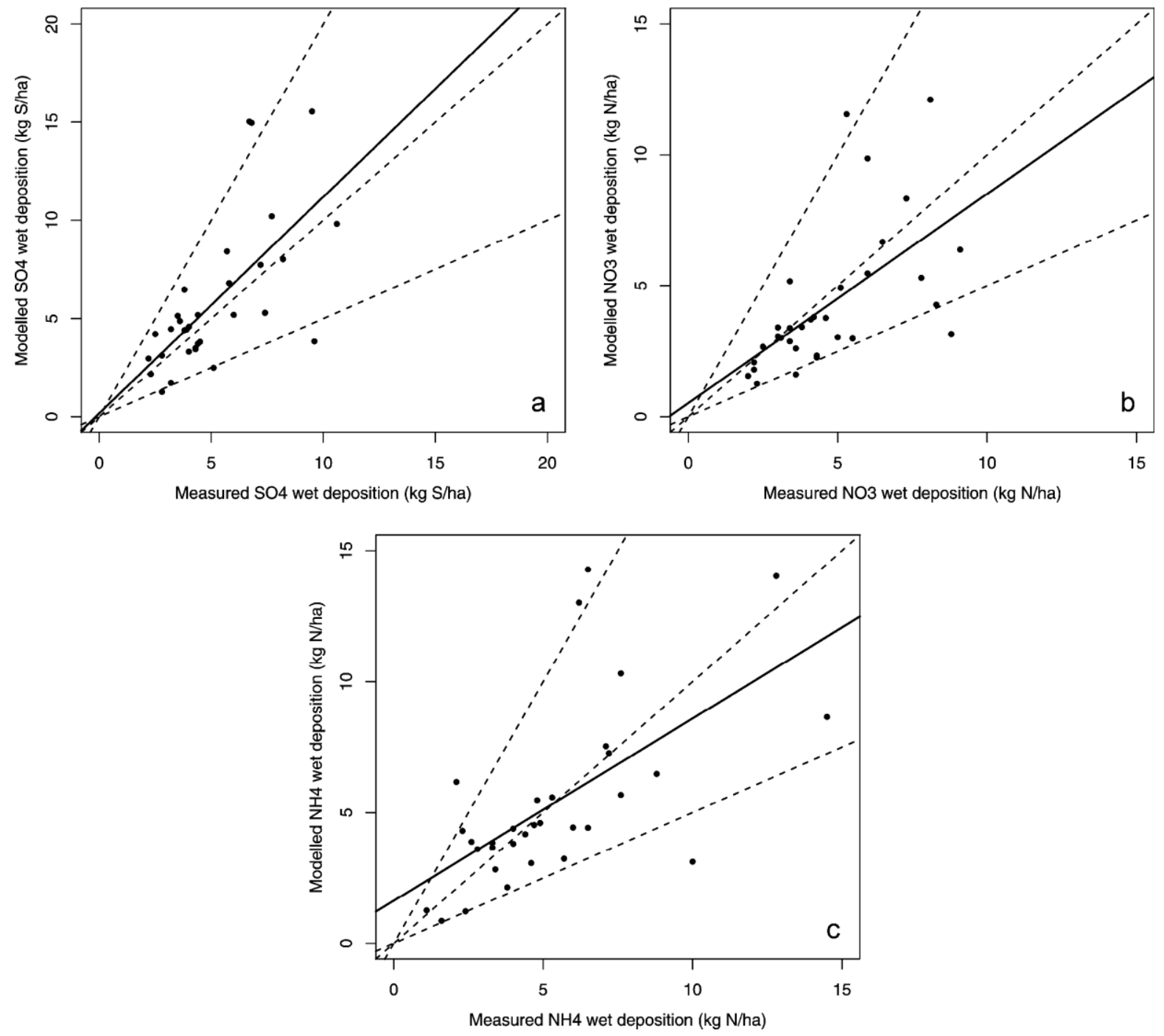

Fig. 2. Correlation of modelled wet deposition with measurements from the national monitoring network for 2005: a) $\mathrm{SO}_{4}{ }^{2-}$, b) $\mathrm{NO}_{3}{ }^{-}$, c) $\mathrm{NH}_{4}{ }^{+}$, Solid line is the best fit line produced by a regression analysis, dashed lines are for reference: $2: 1,1: 2$ and $1: 1$ division

Comparison of the model with measurements shows that FRAME gives reasonable agreement with measurements. The second part of the validation is the country deposition budget comparison. The FRAME wet deposition budgets for the UK show reductions of 132 Gg S-SO $\mathrm{yr}^{-1}, 15 \mathrm{Gg}$ N-NO $\mathrm{yr}^{-1}$ and $19 \mathrm{Gg} \mathrm{N}^{-N H_{x}}$ yr-1 over the period 1990-2005 (Fig. 3). 
There is a very good fit between modelled and measured lines, especially for the second part of the period, for which emission data are more precise. FRAME tends to constantly give higher values for $\mathrm{SO}_{\mathrm{x}}$ deposition, and lower for $\mathrm{NO}_{\mathrm{y}}$ in comparison to measurements. There is no general rule for $\mathrm{NH}_{\mathrm{x}}$, which can be over and underestimated in different years. The highest differences between modelled and measured data are for $\mathrm{NO}_{\mathrm{y}}$, and the lowest for $\mathrm{NH}_{\mathrm{x}}$.

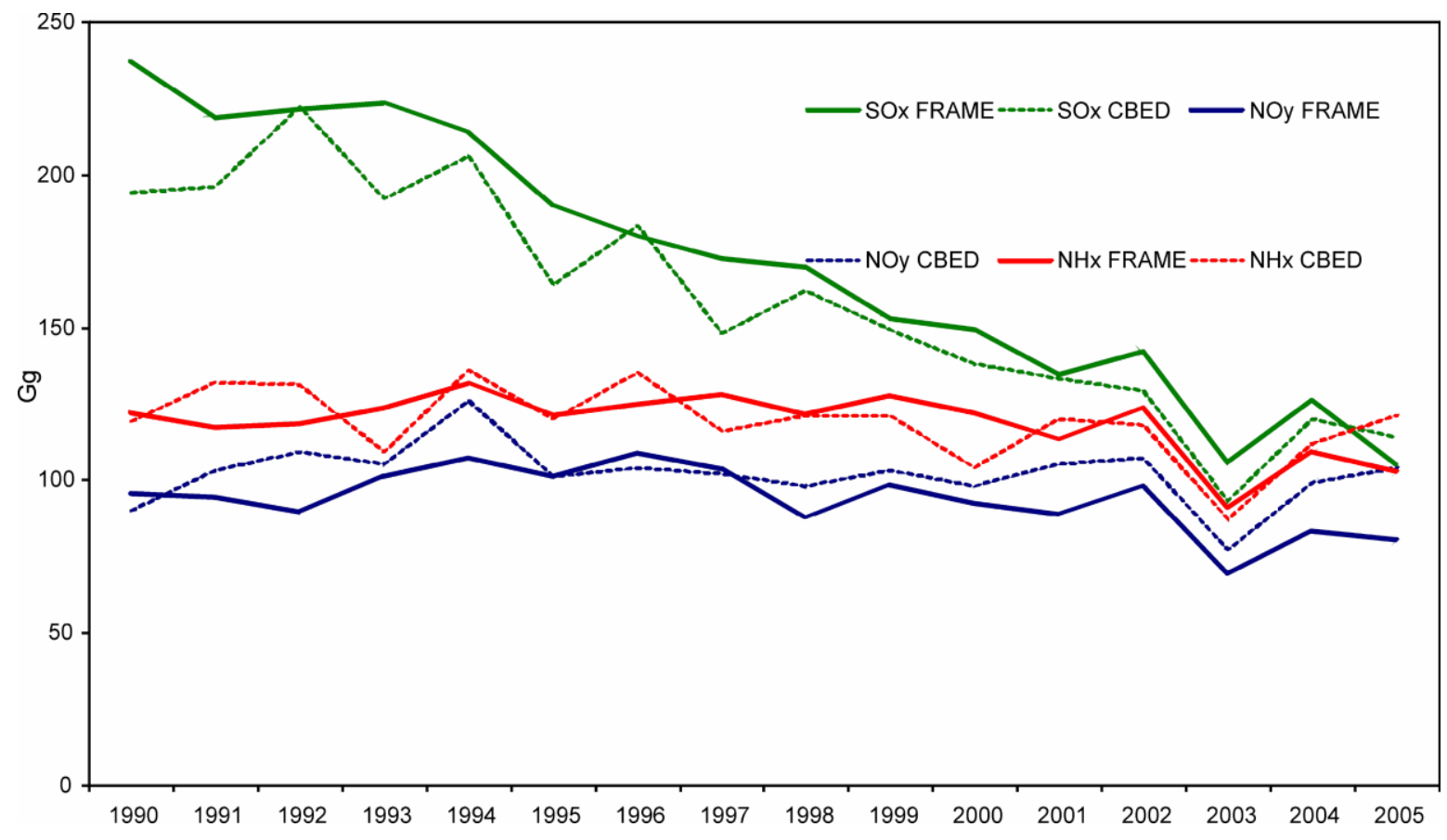

Fig. 3. Modelled and measured UK national wet deposition budget for: $\mathrm{S}-\mathrm{SO}_{\mathrm{x}}, \mathrm{N}-\mathrm{NO}_{\mathrm{y}}, \mathrm{N}-\mathrm{NH}$

\subsection{Trends in emissions}

UK emissions of $\mathrm{S}-\mathrm{SO}_{2}, \mathrm{~N}-\mathrm{NO}_{\mathrm{x}}$ and $\mathrm{N}-\mathrm{NH}_{3}$ are presented in Fig. 4. There have been significant reductions in $\mathrm{S}-\mathrm{SO}_{2}$ emissions since 1970, the emission in 2005 representing $89 \%$ reduction on the 1970 value. These have been caused by fuel switching from coal to gas, and the installation of abatement equipment (flue gas desulphurisation) at power stations. 
Measures to abate emissions of $\mathrm{SO}_{2}$ have proved to be highly effective. Significant reductions are also evident from other sources, most notably Industrial and Residential Combustion . This is caused by the increased use of gas in place of coal.

Emission projections are available for selected years to 2020, and are expected to be driven by the extent to which coal is used in public electricity generation. The current projection for 2010 shows that the UK is expected to achieve the ceiling of $293 \mathrm{Gg} \mathrm{S}-\mathrm{SO}_{2}$ required by the European Commissions National Emissions Ceilings Directive (NECD). Estimates for 2020 indicate a 50\% reduction on the 2005 emission total. Emission estimates of $\mathrm{SO}_{2}$ are considered to be relatively low in uncertainty $( \pm 4 \%)$. This is because the most important datasets for making the emissions estimates (mass of fuel, and the corresponding sulphur content) are considered to be well characterised.

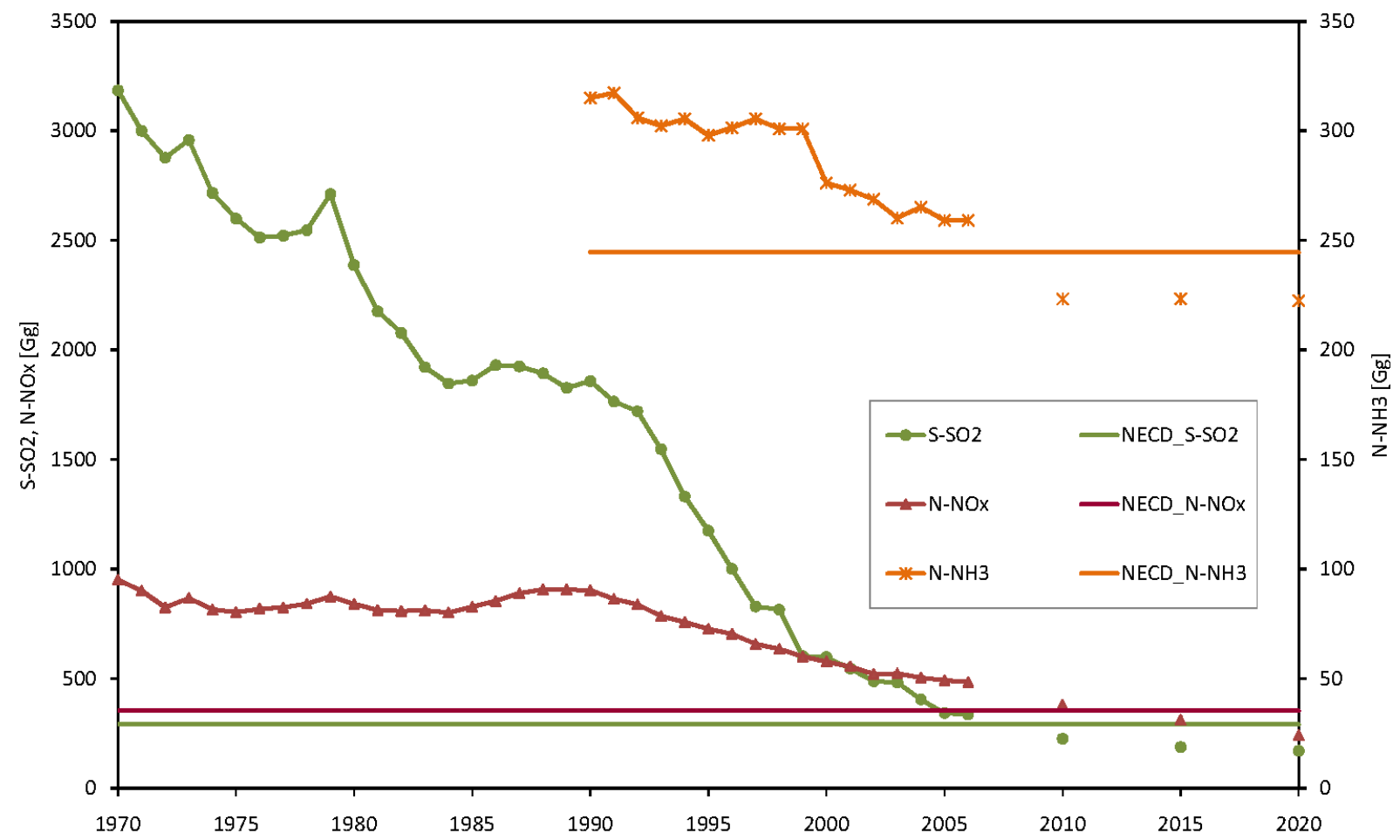

Fig. 4. Trend in UK emissions of $\mathrm{S}-\mathrm{SO}_{2}, \mathrm{~N}-\mathrm{NO}_{\mathrm{x}}, \mathrm{N}-\mathrm{NH}_{3}(\mathrm{Gg})$

There have been significant reductions in emissions of $\mathrm{N}-\mathrm{NO}_{\mathrm{x}}\left(\right.$ as $\mathrm{N}-\mathrm{NO}_{2}$ ) from a number of sources, the decrease from 1970 to 2005 representing a reduction of $48 \%$. The largest 
emission reduction has been from Passenger Cars. This is due to the introduction of threeway-catalysts in the late 1990's and subsequently a number of increasingly stringent emission standards. More recently emission standards have also been introduced for heavy duty vehicles. Emissions from power generation have also reduced, primarily due to the increased use of gas over coal fired stations. Gas fired power stations emit less $\mathrm{NO}_{\mathrm{x}}$, and are typically more efficient. Recent years have shown a slight increase in $\mathrm{NO}_{\mathrm{x}}$ emissions from power generation. This is because coal has been used in favour of gas, driven by a more attractive fuel price.

Until recently emission projections had indicated that the UK was on target to meet the NECD of $346 \mathrm{Gg} \mathrm{N}-\mathrm{NO}_{\mathrm{x}}$. However, current emission projections for 2010 show that this is not the case. This change has been caused by the re-evaluation of emissions from new cars entering the vehicle fleet which complied with a particular emissions standard. Originally emission estimates were based on studies undertaken on rolling roads in the laboratory. However more recent real world testing has shown that these vehicles do not provide the reductions previously thought. As a result the emission estimate for 2010 was revised and increased, taking it above the NECD target for 2010. Emission estimates for 2020 indicate a $51 \%$ reduction on the 2005 UK emissions total.

Emissions are presented as $\mathrm{NO}_{\mathrm{x}}$ (as $\mathrm{NO}_{2}$ equivalent), and as such do not provide a true indication of the $\mathrm{NO}_{2}$ emissions. It is known that the $\mathrm{NO}_{2}: \mathrm{NO}_{\mathrm{x}}$ ratio of emissions has increased in recent years for a number of reasons. The most important reasons in recent years that could affect the $\mathrm{NO}_{2} / \mathrm{NO}_{\mathrm{x}}$ emissions ratio have been the programme of fitting diesel particulate filters (DPSs) to buses. It was reported that emission of $\mathrm{NO}_{2}: \mathrm{NO}_{\mathrm{x}}$ increased from $5 \%$ without a CDPF to 15-20\% (DRSTA, 2002). Another factor is the increased use of diesel cars. It is known that diesel vehicles tend to have a higher $\mathrm{NO}_{2}: \mathrm{NO}_{\mathrm{x}}$ emission ratio, particularly under low engine load conditions (Carslaw, 2005; AQEG, 2004). This has meant 
that measures taken to reduce $\mathrm{NO}_{\mathrm{x}}$ emissions have not resulted in the reduction in $\mathrm{NO}_{2}$ concentrations which were anticipated. Levels of $\mathrm{NO}_{\mathrm{x}}$ from combustion sources are heavily dependent on a range of combustion parameters. As a result uncertainties are higher. The UK $\mathrm{NO}_{\mathrm{x}}$ emission totals are quoted with an uncertainty of $\pm 10 \%$.

Emission estimates of $\mathrm{N}-\mathrm{NH}_{3}$ are only presented for 1990 onwards as data is incomplete prior to this. Emissions of $\mathrm{NH}_{3}$ are dominated by agricultural activities, and cattle manure management in particular. There are numerous national policies in place to manage nitrogen emissions from the agricultural sector. However, it has proved difficult to have any significant impact on $\mathrm{NH}_{3}$ emissions from this politically sensitive source sector. Whilst the reduction in emissions of $\mathrm{N}-\mathrm{NH}_{3}$ observed in Fig. 4, is not as large as that for $\mathrm{S}-\mathrm{SO}_{2}$ or $\mathrm{N}-\mathrm{NO}_{\mathrm{x}}$, there was an $18 \%$ reduction from 1990 to 2006 . This has primarily been driven by a decrease in livestock numbers, changes to animal diet and improvements to manure management. Emissions of $\mathrm{NH}_{3}$ are high in uncertainty, the UK emissions total being quoted as $\pm 20 \%$. So, whilst the current best estimate for $2010\left(242 \mathrm{Gg} \mathrm{N}-\mathrm{NH}_{3}\right)$ does give a total which is lower than the $2010 \mathrm{NECD}$ target $\left(245 \mathrm{Gg} \mathrm{N}-\mathrm{NH}_{3}\right)$, the uncertainty range does extend above the ceiling.

The FRAME model was run for the year 2005 firstly with all emissions sources, secondly with European emissions removed, and thirdly with shipping emissions removed (in both the European and UK simulations). These simulations allowed assessment of the relative contribution of UK emissions, shipping emissions and European emissions to deposition of sulphur and nitrogen in the UK. The FRAME results have been compared with the EMEP source-receptor matrices for the year 2005.

These calculations showed that with FRAME $22 \%$ of sulphur deposition was attributed to European sources and $19 \%$ to international shipping. This showed good agreement with EMEP figures of $25 \%$ and $19 \%$ respectively. For $\mathrm{NO}_{\mathrm{y}}$ deposition FRAME attributed $15 \%$ of 
deposition to shipping and $27 \%$ to European sources (EMEP $18 \%$ and $40 \%$ respectively). For $\mathrm{NH}_{\mathrm{x}}$, FRAME attributed $30 \%$ of deposition to European sources compared with $27 \%$ for EMEP.

\subsection{Recent trends in deposition of sulphur and nitrogen (1990-2005)}

Over the period 1990-2005 modelled total (wet + dry) deposition in the UK decreased from 413 to $157 \mathrm{Gg} \mathrm{S} \mathrm{SO}_{\mathrm{x}} \mathrm{yr}^{-1}$. For nitrogen, annual total deposition decreased from 176 to $148 \mathrm{Gg}$ for $\mathrm{N}-\mathrm{NO}_{\mathrm{y}}$ and from 193 to $169 \mathrm{Gg}$ if reduced nitrogen is considered. These figures account for $62 \%, 16 \%$ and $12 \%$ decreases in total deposition of $\mathrm{SO}_{\mathrm{x}}, \mathrm{NO}_{\mathrm{y}}$ and $\mathrm{NH}_{\mathrm{x}}$ respectively. Dry deposition declined more than wet for $\mathrm{SO}_{\mathrm{x}}$ but for $\mathrm{NO}_{\mathrm{y}}$ and $\mathrm{NH}_{\mathrm{x}}$ the percentage changes of wet and dry deposition were almost the same. During the early nineties wet deposition comprised $57 \%, 54 \%, 63 \%$ of total deposition of $\mathrm{SO}_{\mathrm{x}}, \mathrm{NO}_{\mathrm{y}}$, and $\mathrm{NH}_{\mathrm{x}}$, respectively, in 2005 the value increased by some $10 \%$ for $\mathrm{SO}_{\mathrm{x}}$ and has not changed significantly for $\mathrm{NO}_{\mathrm{y}}$ and $\mathrm{NH}_{\mathrm{x}}$.

Fig. 5, 6, 7 show percentage change in UK average annual precipitation, national emissions and wet deposition of $\mathrm{SO}_{\mathrm{x}}, \mathrm{NO}_{\mathrm{y}}, \mathrm{NH}_{\mathrm{x}}$ normalised against a 1990 baseline. The results suggest that wet deposition has decreased less quickly than emissions. Wet deposition decreased between 1990 and 2005 by $55 \%$ for $\mathrm{SO}_{\mathrm{x}}$ and by about $16 \%$ for $\mathrm{NO}_{\mathrm{y}}$ and $\mathrm{NH}_{\mathrm{x}}$, whereas the reduction in emission for $\mathrm{SO}_{\mathrm{x}}$ and $\mathrm{NO}_{\mathrm{y}}$ was significantly higher (by $77 \%, 47 \%$, respectively) and by $18 \%$ for $\mathrm{NH}_{\mathrm{x}}$. The changes in emission and deposition are not closely correlated. There are some years, especially for $\mathrm{NO}_{\mathrm{y}}$ and $\mathrm{NH}_{\mathrm{x}}$, where emissions have decreased but wet deposition increases. Comparing the years 1993-1997, emissions of $\mathrm{NO}_{\mathrm{y}}$ decreased by about 15 to $30 \%$ relative to 1990 , while wet deposition is higher on average by $10 \%$ than in 1990. A similar situation is observed for $\mathrm{NH}_{\mathrm{x}}$. If the two driest years (1996 and 2003) are compared, there is a good agreement between emission and deposition for 2003 but not for 1996. This can be explained by inter-annual variation of meteorology conditions. As 
discussed above, the period 1993-1997 was characterized by a high frequency of E-SE-S wind directions (the most polluted sector). The lack of linearity in changing of emission and deposition has been explained by other authors (Irwin et al., 2002; Fournier et al., 2004; Hall et al., 2006). This was attributed to a number of factors including increases in emissions from international shipping, changing in European emission and changing rates of atmospheric oxidation. During the years 1990-2005, when the larges changes of emission occurred, when UK emission of $\mathrm{SO}_{\mathrm{x}}, \mathrm{NO}_{\mathrm{x}}, \mathrm{NH}_{\mathrm{x}}$ decreased by $77 \%, 47 \%$ and $18 \%$ respectively, European emissions showed similar trends, with decreases of $66 \%, 30 \%$ and $21 \%$, respectively. These changes influence the ratio of pollutants imported to national emissions but indicate that the relative contribution of imported pollutants from Europe to the UK has not been subject to large changes.

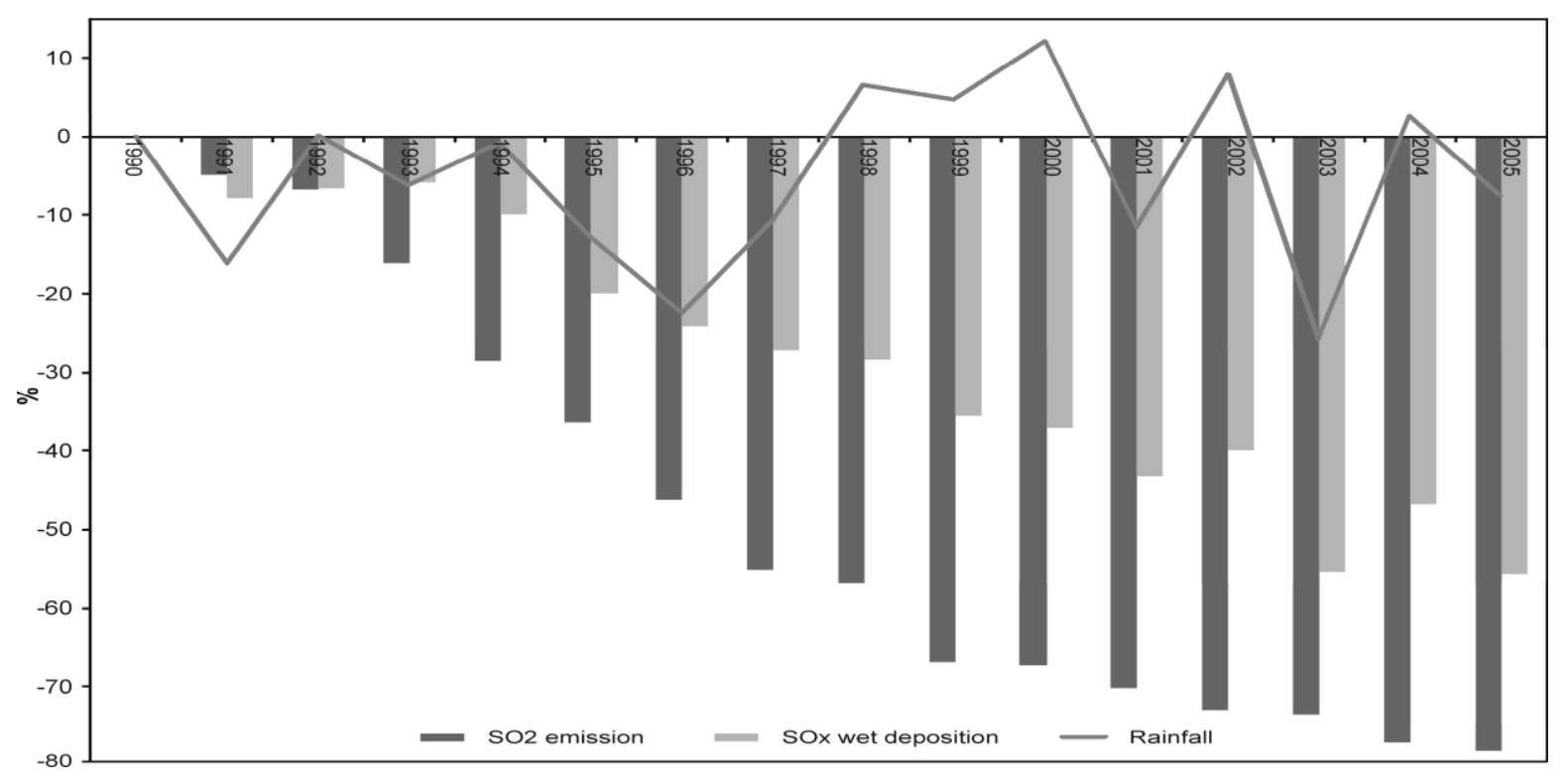

Fig. 5. Percentage change in average network precipitation, national $\mathrm{SO}_{2}$ emissions and $\mathrm{SO}_{\mathrm{x}}$ wet deposition normalised against 1990 baseline 


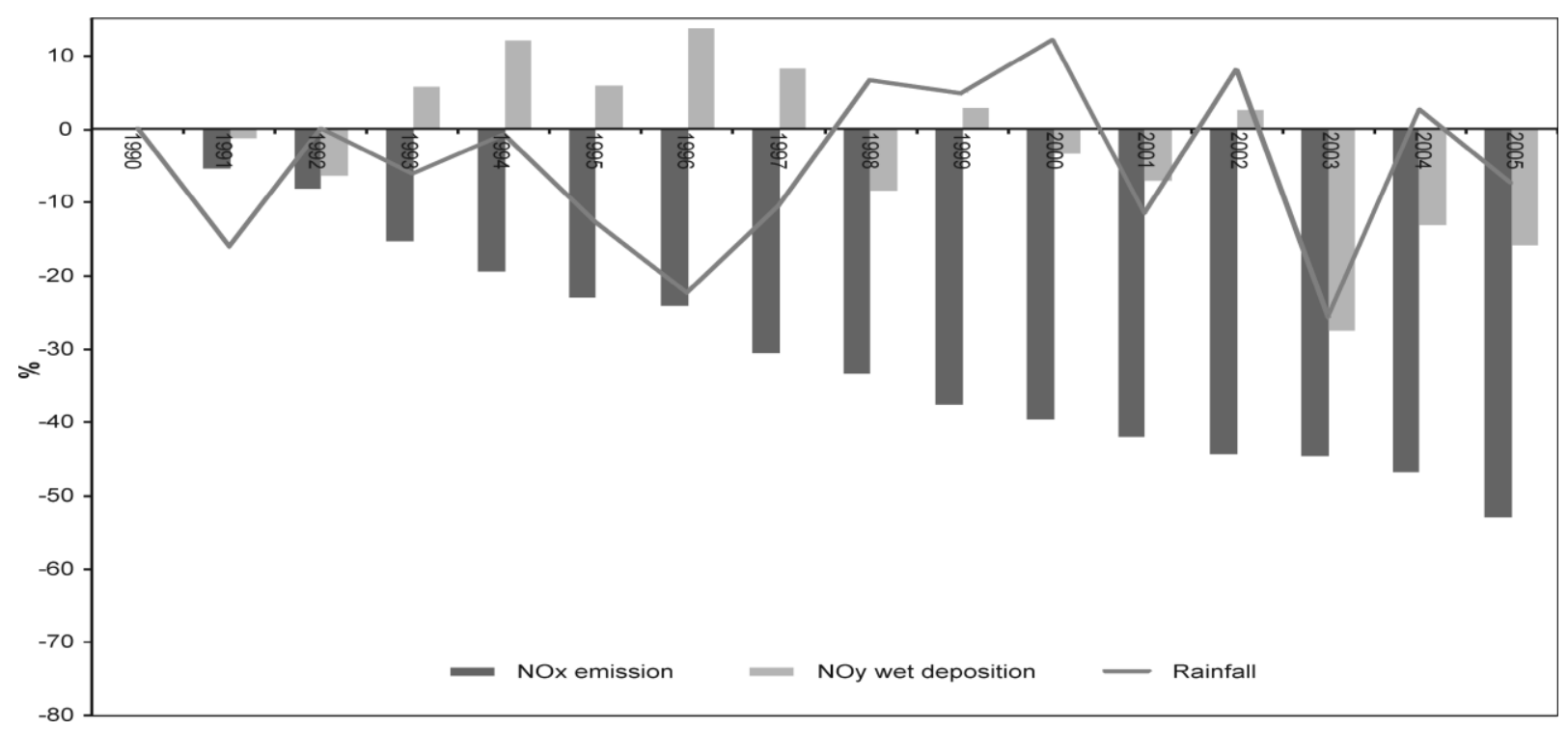

Fig. 6. Percentage change in average network precipitation, national $\mathrm{NO}_{\mathrm{x}}$ emissions and $\mathrm{NO}_{\mathrm{y}}$ wet deposition normalised against 1990 baseline

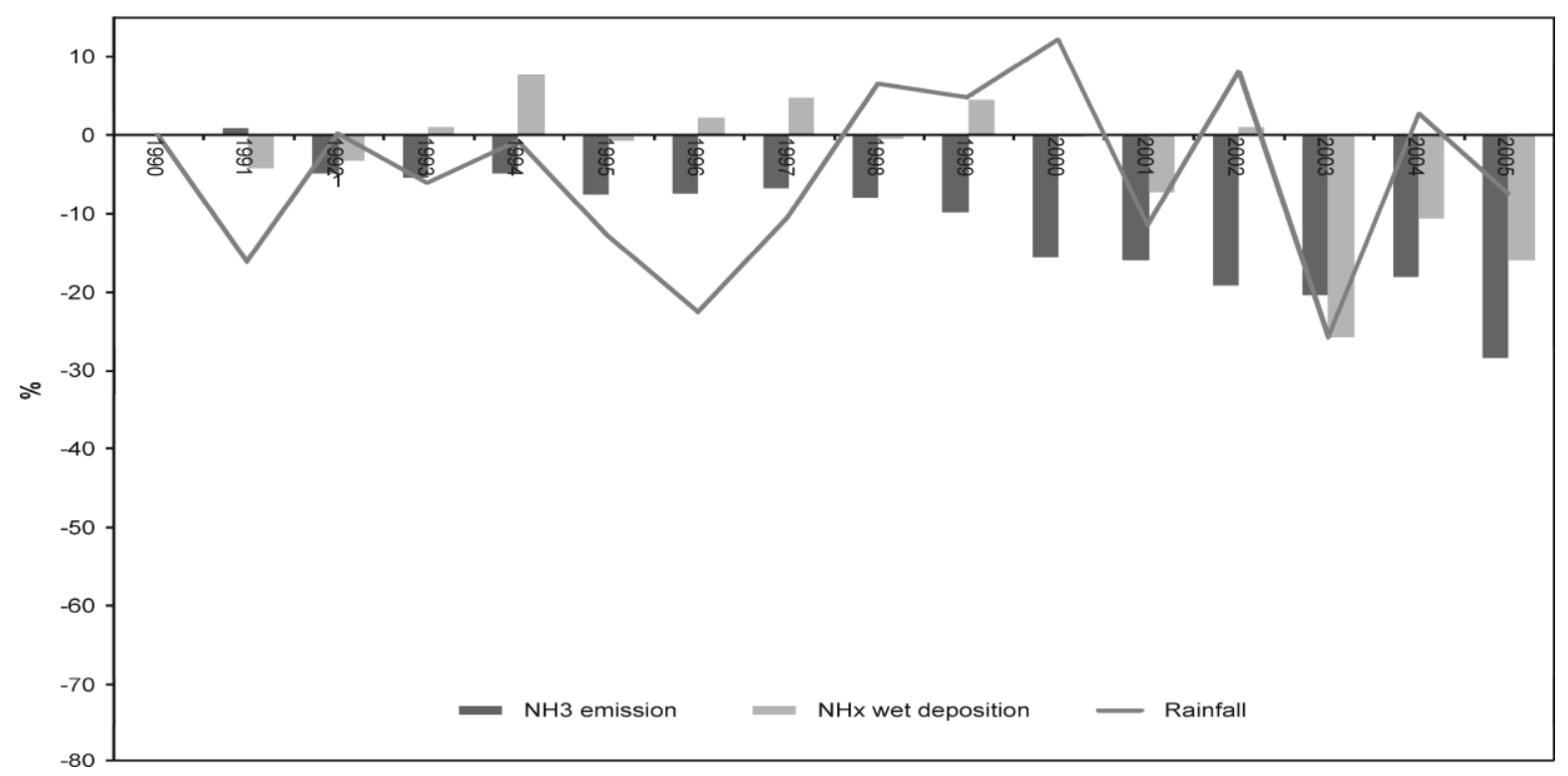

Fig. 7. Percentage change in average network precipitation, national $\mathrm{NH}_{3}$ emissions and $\mathrm{NH}_{\mathrm{x}}$ wet deposition normalised against 1990 baseline

\subsection{Long term trends in deposition and exceedances of critical loads of sulphur and} nitrogen (1970-2020)

The deposition of sulphur, oxidised and reduced nitrogen calculated by FRAME for the year 1970 is illustrated in Fig. 8(a) - (f). These can be compared with deposition maps for 
a future year (2020, Fig. 9 (a) - (f)). A striking change in deposition is apparent during the 50 year time period. For sulphur, both dry and wet deposition in 1970 exceeded $20 \mathrm{~kg} \mathrm{~S} \mathrm{ha}^{-1} \mathrm{yr}^{-1}$ in much of the country. By the year 2005, dry deposition exceeds $5 \mathrm{~kg} \mathrm{~S} \mathrm{ha}^{-1} \mathrm{yr}^{-1}$ only in some industrial areas of northern England and in the south-east although many areas have wet deposition of sulphur in excess of $5 \mathrm{~kg} \mathrm{~S} \mathrm{ha}^{-1} \mathrm{yr}^{-1}$. By 2020, only a restricted region receives annual deposition in excess of $5 \mathrm{~kg} \mathrm{~S} \mathrm{ha}^{-1} \mathrm{yr}^{-1}$, corresponding to the high rainfall areas of the Pennines and the some coastal regions which are strongly influenced by shipping emissions. A similar pattern is apparent for $\mathrm{NO}_{\mathrm{y}}$ deposition. Upland regions and areas influenced by vehicle emissions are subject to deposition (both wet and dry) in excess of $10 \mathrm{~kg} \mathrm{~N} \mathrm{ha}^{-1} \mathrm{yr}^{-1}$. By 2020 the regions where deposition exceeds $5 \mathrm{~kg} \mathrm{~N}^{-1} \mathrm{yr}^{-1}$ are restricted to a small number of coastal sites, urban regions and some upland sites. For $\mathrm{NH}_{\mathrm{x}}$ deposition, the changes are generally smaller during the 50 year time period due to much smaller reductions in emissions. 


\section{a}
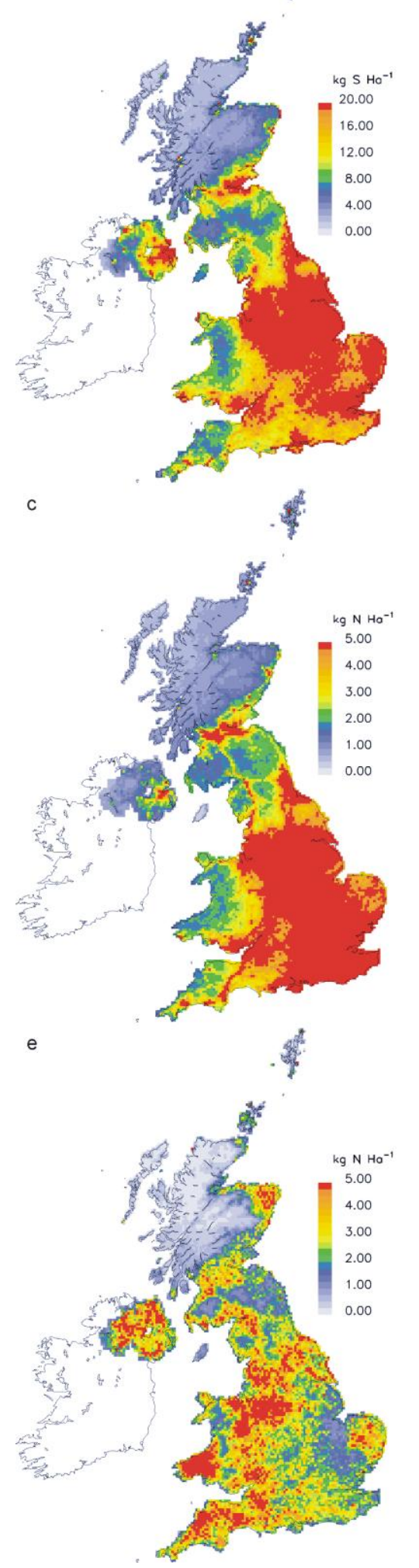

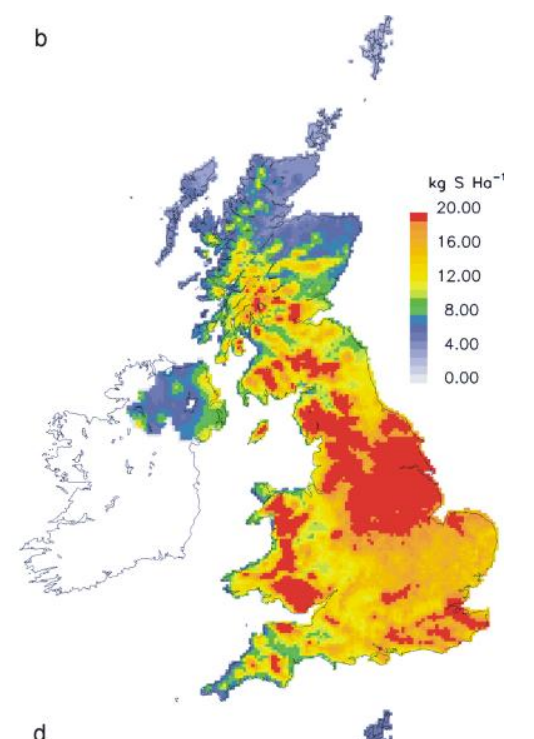

d
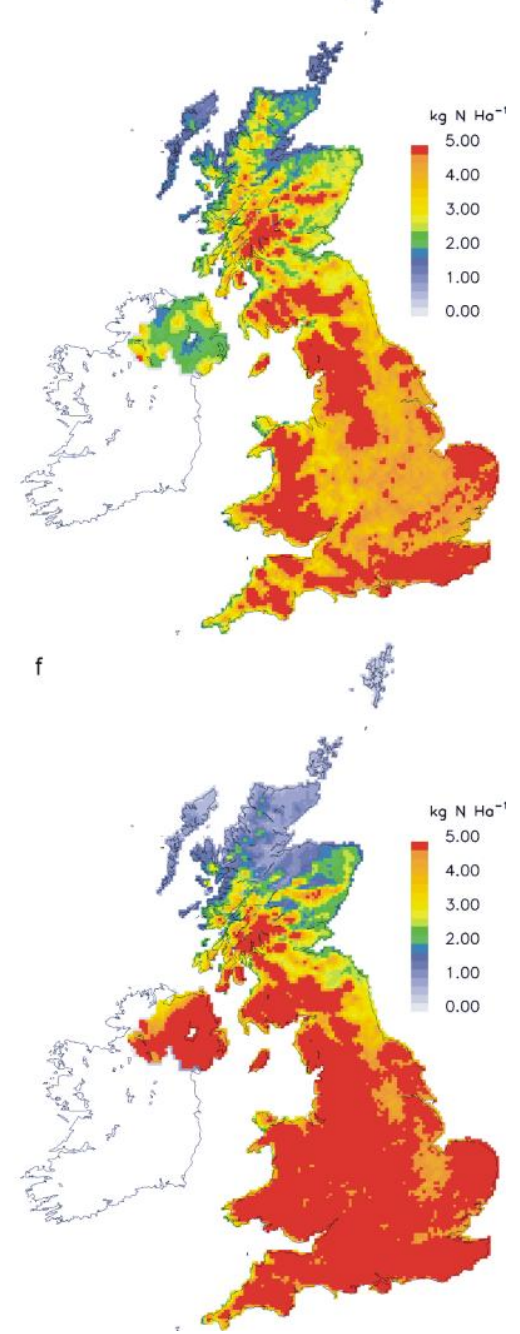

Fig. 8. FRAME 1970 deposition: a) $\mathrm{SO}_{\mathrm{x}}$ dry; b) $\mathrm{SO}_{\mathrm{x}}$ wet; c) $\mathrm{NO}_{\mathrm{y}}$ dry; d) $\mathrm{NO}_{\mathrm{y}}$ wet; e) $\mathrm{NH}_{\mathrm{x}}$ dry f) $\mathrm{NH}_{\mathrm{x}}$ wet (kg S or $\left.\mathrm{Nha}^{-1} \mathrm{yr}^{-1}\right)$ 
a
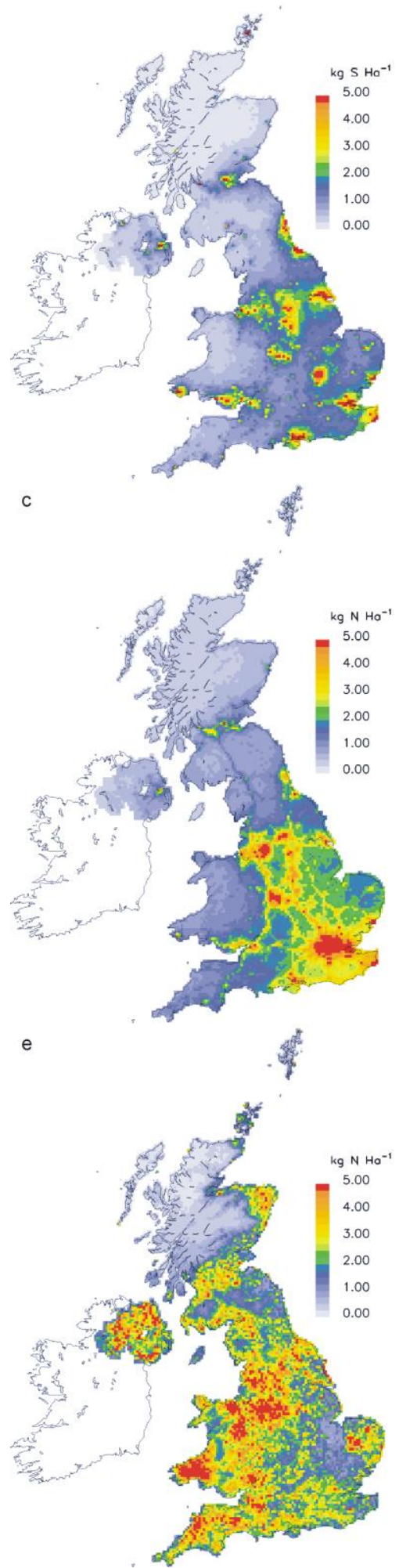

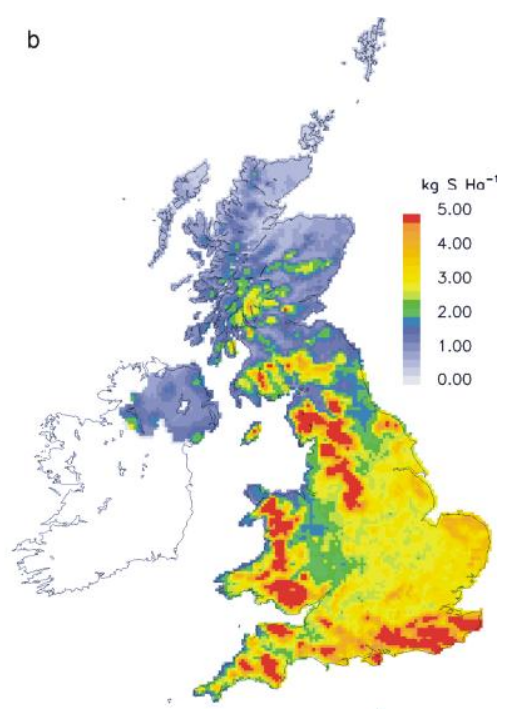

d
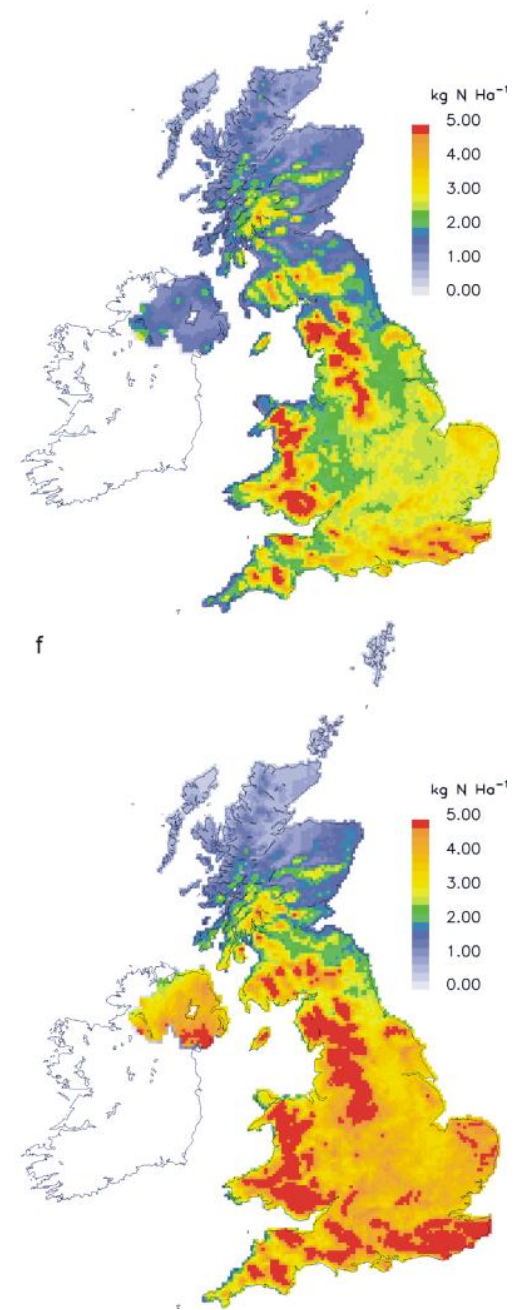

Fig. 9. FRAME 2020 deposition: a) $\mathrm{SO}_{\mathrm{x}}$ dry; b) $\mathrm{SO}_{\mathrm{x}}$ wet; c) $\mathrm{NO}_{\mathrm{y}}$ dry; d) $\mathrm{NO}_{\mathrm{y}}$ wet; e) $\mathrm{NH}_{\mathrm{x}}$ dry f) $\mathrm{NH}_{\mathrm{x}}$ wet $(\mathrm{kg} \mathrm{S}$ or $\left.\mathrm{Nha}^{-1} \mathrm{yr}^{-1}\right)$ 
A description of the methods used to derive and calculate critical loads is given in Hall et al. (2003). The exceedances of critical loads of acidity and nutrient nitrogen across the UK were calculated using the FRAME data for 1970, 2005 and 2020. The significant reduction in the areas with exceedance is mapped in Fig. 10 (a) and (b). The larges changes are noticed close to the emission sources, whereas in hilly regions there are large exceedances also in 2020 . For acidity, the habitat areas with deposition exceeding critical loads are seen to fall significantly between 1970 and 2020 (from 94\% to $22 \%$ for dwarf shrub heath). However, for nutrient nitrogen, the percentage area of unmanaged forest exceeded falls only marginally, from $99 \%$ to $95 \%$ between 1970 and 2020 (Fig. 11). This is due to the dominant role of dry deposition of ammonia to tall vegetation. The total area of sensitive UK habitats exceeded fell from $85 \%$ to $37 \%$ for acidity and from $73 \%$ to $49 \%$ for nutrient nitrogen.

Reductions in acid deposition and total nitrogen deposition may provide the conditions in which chemical and biological recovery of sensitive habitats can begin, but the timescales of these processes are often very long relative to the timescales for reductions in emissions. The study demonstrates the increasing relative importance of ammonia emissions in contributing to eutrophication and acidification. Efforts to further reduce deposition of sulphur and nitrogen to the natural environment must include measures to control emissions of ammonia. 


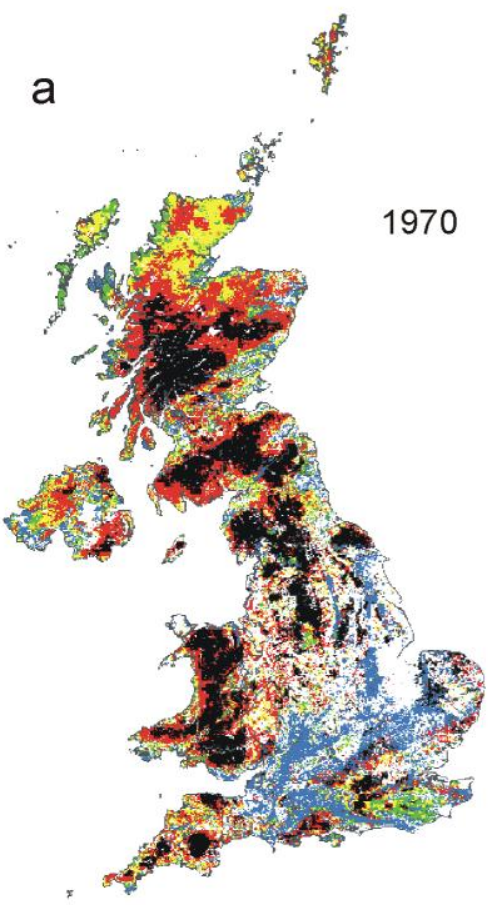

$$
4
$$

4
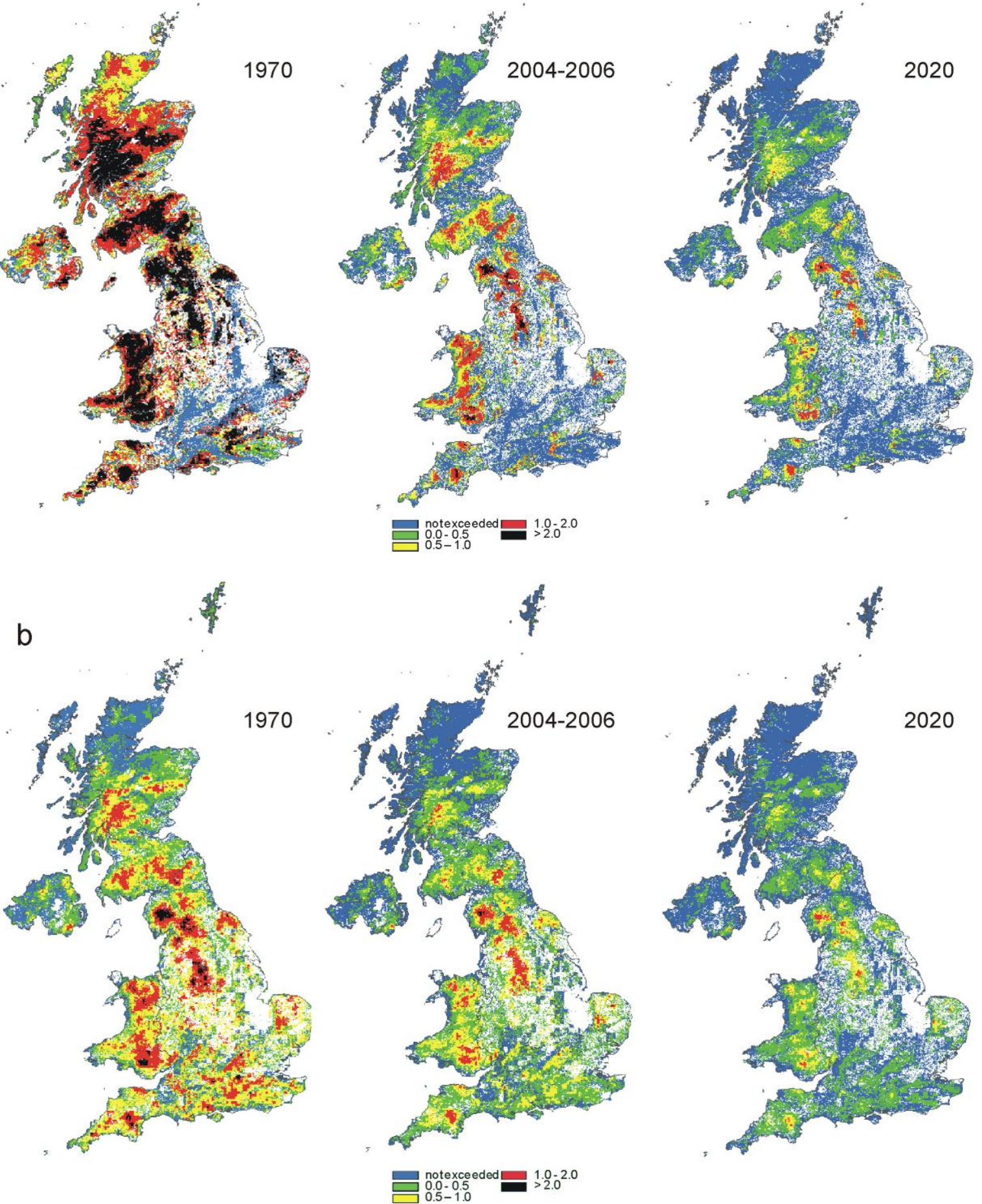

Fig. 10. Exceedance of $5^{\text {th }}$-percentile acidity critical loads by a) acid deposition b) nitrogen deposition (keq/ha) 


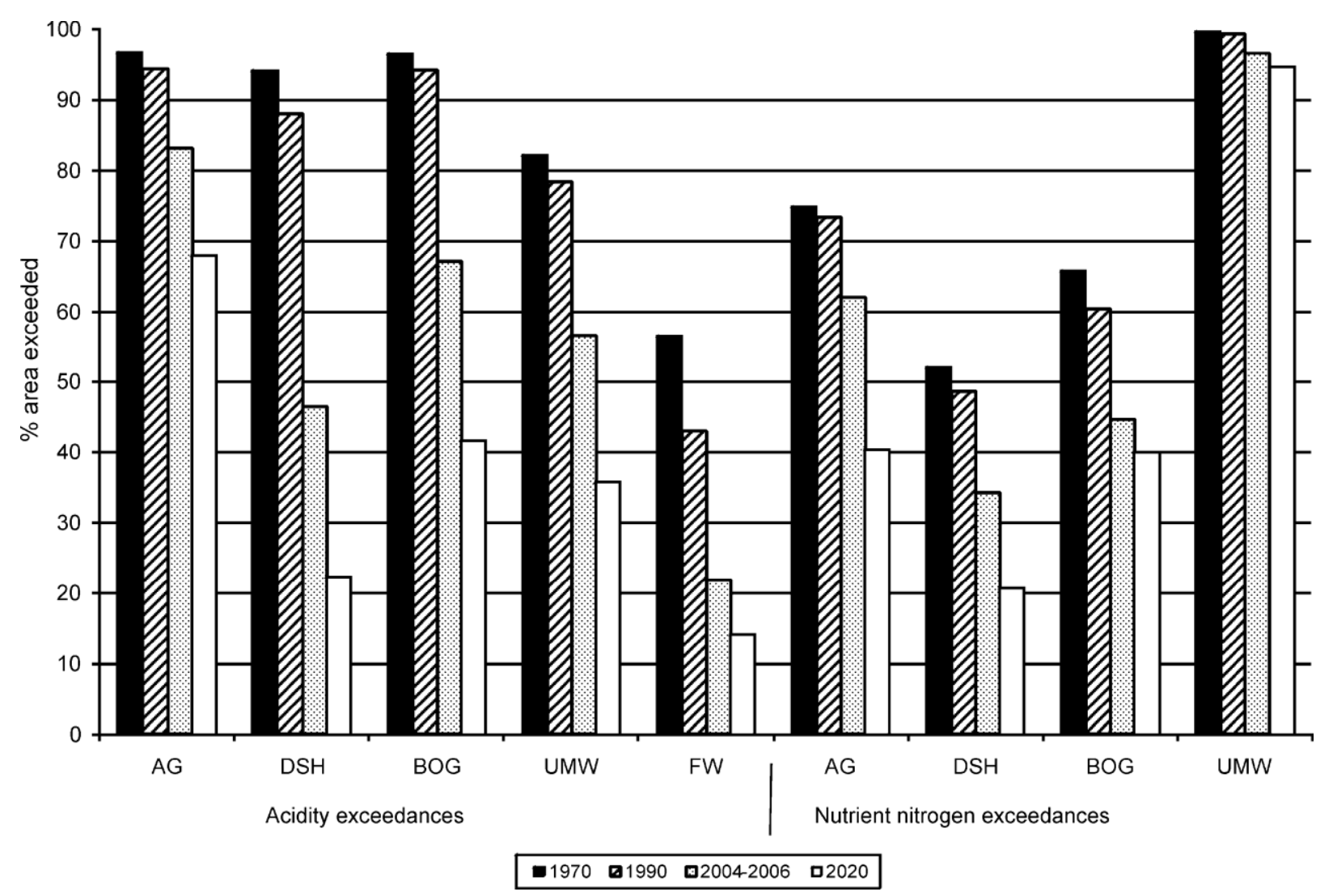

Fig. 11. The percentage of system area in the UK with exceedance of critical loads for deposition of acidity and nitrogen during 1970 to 2020 (AG: Acid Grassland, DSH: Dwarf Shrub Heath, BOG: bog, UMW: unmanaged woodland, FW: freshwater)

\section{Conclusion}

An atmospheric transport model has been applied to assess the influence of reductions in emissions of pollutant gases $\left(\mathrm{SO}_{2}, \mathrm{NO}_{\mathrm{x}}, \mathrm{NH}_{3}\right)$ on sulphur and nitrogen deposition in the UK during a 50 year time period (1970-2020). The results of the model were compared with measurements of wet deposition $\left(\mathrm{SO}_{4}{ }^{2-}, \mathrm{NO}_{3}{ }^{-}, \mathrm{NH}_{4}{ }^{+}\right)$from the $\mathrm{UK}$ national monitoring network covering the period 1990 to 2005 . Both the model and the measurements showed that reductions in deposition during this 15 year period were less significant than the reductions in emissions. For the period 1990-2005 emissions decreased by $77 \%$ for $\mathrm{SO}_{\mathrm{x}}, 47 \%$ for $\mathrm{NO}_{\mathrm{y}}$ and $18 \%$ for $\mathrm{NH}_{\mathrm{x}}$, whereas the reduction in modelled wet deposition amounted to $55 \%, 16 \%$ and $12 \%$, respectively. This was attributed partly to the effect of import of pollutants to the UK from international shipping emissions which have increased significantly during recent years. 
The large decrease in $\mathrm{SO}_{2}$ concentrations in the UK during recent decades has resulted in an increase in the oxidising capacity of the atmosphere with the result that precursor gases $\left(\mathrm{SO}_{2}\right.$ and $\mathrm{NO}_{\mathrm{x}}$ ) can be more rapidly oxidised and converted to sulphate and nitrate aerosol. These particulates play an important role in the long range transport of pollutants and deposition of sulphur and nitrogen, particularly in high rainfall upland areas.

Analysis of meteorological data showed that inter-annual variation of circulation patterns and precipitation played a significant role in causing year to year fluctuations in deposition, such that deposition could increase in years with high annual precipitation or enhanced circulation from the polluted south-easterly sector. Such inter-annual variation in meteorology can confound attempts to detect trends in deposition through measurement. Long term data series of wet deposition of approximately two decades are required to measure deposition trends. One advantage with a modelling approach is that it is possible to separate the influence of emissions and meteorology on deposition by running simulations either with fixed meteorology and inter-annual variation in emissions or with inter-annual variation in both emissions and meteorology. Future application of complex Eulerian atmospheric transport models using detailed meteorological drivers and sophisticated photo-oxidation schemes is recommended for further studies in deposition trends.

Long term trends in deposition modelled from 1970 to 2020 show that the large decrease $(95 \%)$ in emissions of $\mathrm{SO}_{2}$ from the UK during this period have resulted in significant decreases $(87 \%)$ in total sulphur deposition and corresponding decreases to exceedance of critical loads (from $85 \%$ to $37 \%$ of area) to many vegetation types. Reductions in nitrogen deposition are smaller during this time period, in part due to relatively small reductions of ammonia emissions. Whilst the area of vegetation in the UK with exceedance of critical loads for deposition to acid grassland, dwarf shrub heath and bog has shown improvement, exceedance of deposition to unmanaged woodland remains high. Future 
reductions in exceedance of critical loads for nitrogen deposition will require application of focused policy to abate emissions of ammonia from agricultural sources.

\section{Acknowledgement:}

This work was funded by the UK Department of the Environment, Food and Rural Affairs and the Natural Environment Research Council.

\section{References:}

ApSimon, H. M., Barker B. M., Kayin S.,1994. Modelling studies of the atmospheric release and transport of ammonia - applications of the TERN model to an EMEP site in eastern England in anticyclonic episodes. Atmospheric Environment, 28, 665-678.

AQEG, 2004. Nitrogen dioxide in the United Kingdom. Report prepared by the Air Quality Expert Group for the Department for Environment, Food and Rural Affairs; Scottish Execuitive, Welsh Assembly Government; and Department of Environment in Northern Ireland.

Barrett K., O. Seland, 1995., European Transboundary Acydifying Air Pollution - Ten years calculated field and budgets to the end of the first Sulphur Protocol. EMEP, 1/95, Norwegian Meteorological Institute Oslo, Norway.

Berge, E., Bartnicki, J., Olendrzyński, K., Tsyro, S.G., 1999. Long-term trends in emissions and transboundary transport of acidifying air pollution in Europe. Journa of Environmental Management 57, 31-50.

Błaś, M., Dore, A.J., Sobik, M., 1999. Distribution or precipitation and wet deposition around an island mountain in south-west Poland. Quarterly Journal of the Royal Meteorological Society $125,253-270$.

Błaś, M., Sobik, M., Twarowski, R., 2008. Changes of cloud water chemical composition in the Western Sudety Mountains, Poland. Atmospheric Research 87, 224-231.

Carslaw, D., 2005. Evidence of an increasing $\mathrm{NO}_{2} / \mathrm{NO}_{\mathrm{x}}$ emissions ratio from road traffic emissions. Atmospheric Environment 39, 4793-4802.

Chang, J.C.; Hanna, S.R. Air quality model performance evaluation. Met. and Atm. Phys. 2004, 87, 167-196.

Choularton, T. W., Gay, M. J., Jones, A., Fowler, D., Cape, J. N., Leith, I. D., 1988. The influence of altitude on wet deposition. Comparison between field measurements at Great Dun Fell and the predictions of the seeder-feeder model. Atmospheric Environment 22, 1363-1371.

Corbett, J. J., and H. W. Köhler, 2003. Updated emissions from ocean shipping, J. Geophys. Res., 108(D20), 4650.

Davies, J.J.L., Jenkins, A., Monteith, D.T., Evans, C.D., Cooper, D.M., 2004. Trends in surface water chemistry of acidified UK freshwaters, 1988-2002. Environmental Pollution 137, 27-39.

DRSTA, 2002. Danish road safety and transport agency. Large scale project with particulate filters on heavy-duty vehicles in Odense. Technical Report. 
Dore, A.J., Choularton, T.W. and Fowler, D., 1992. An improved wet deposition map of the United Kingdom incorporating the seeder-feeder effect over mountainous terrain. Atmospheric Environment 26A, 1375-1381.

Dore, A.J., Vieno, M., Fournier, N., Weston, K.J. and Sutton, M.A., 2006. Development of a new wind rose for the British Isles using radiosonde data and application to an atmospheric transport model. Q.J.Roy.Met.Soc. 132, 2769-2784.

Dore, A. J., Vieno, M., Tang, Y. S., Dragosits, U., Dosio, A., Weston, K. J., Sutton, M. A., 2007. Modelling the atmospheric transport and deposition of sulphur and nitrogen over the United Kingdom and assessment of the influence of $\mathrm{SO}_{2}$ emission from the international shipping, Atmospheric Environment 41, 2355-2367.

EEA, 1998. Europe's Environment: The Second Assessment. Luxemburg: Official Publications of the European Communities, Elsevier Science Ltd.

EMEP, 2006. Transboundary air pollution by main pollutants $\mathrm{S}, \mathrm{N}, \mathrm{O}_{3}$ and $\mathrm{PM}$, The UK, Norwegian Meteorological Institute 57.

Endresen, Ø. E., Sørgård, J. K. Sundet, S. B. Dalsøren, I. S. A. Isaksen, T. F. Berglen, and Gravir, G., 2003. Emission from international sea transportation and environmental impact, J. Geophys. Res., 108(D17), 4560.

ENTEC, 2002. Quantification of emissions from ships associated with ship movements between ports in the European Community. Study for the European Commission (www.europa.eu.int/comm/environment/air/background.htmtransport)

Fagerli, H., Aas, W., 2008. Trends of nitrogen in air and precipitation: Model results and observations at EMEP sites in Europe, 1980-2003. Environmental Pollution 154, 448-461.

Fournier, N., Dore, A. J., Vieno, M., Weston, K. J., Dragosits, U., Sutton, M. A., 2004. Modelling the deposition of atmospheric oxidized nitrogen and sulphur to the UK using a multi-layer longrange transport model, Atmospheric Environment 38, 683-694.

Fowler D., Smith R. I., Muller J. B. A., Hayman G., Vincent K.I., 2004b. Changes in the atmospheric deposition in the UK between 1986 and 2001. Environmental Pollution 137, 15-25.

Fowler, D., Smith, R.I., Müller, J.B.A., Hayman, G., Vincent, K.J., 2005. Changes in atmospheric deposition of acidifying compounds in the UK between 1986 and 2001. Environmental Pollution 137, 15-25.

Fowler, D., Smith, R., Müller, J., Cape, J.N., Sutton, M., Erisman, J.W., Fagerli, H., 2007. Long-term trends in sulphur and nitrogen deposition in Europe and the cause of non-linearities. Water, Air, \& Soil Pollution, Vol. 7, Numbers 1-3, 41-47.

Fowler, D., Cape, N., Smith, R., et al., 2007. Acid Deposition Processes. Final report to Defra. NERC/Centre for Ecology \& Hydrology, 110. (CEH Project Number: C02379, RMP 2258).

Grice, S., T., Bush, J., Stedman, K., Vincent, A., Kent, J., 2005. Baseline Projections of Air Quality in the UK for the 2005 Review of the Air Quality Strategy. AEA Technology, AEAT/ENV/R/1936 Issue 1.

Hall, J., Ullyett, J., Heywood, E., Broughton, R., Fawehinmi, J., 2003. Preliminary assessment of critical loads exceedance. Addendum to status of UK critical loads-methods, data and maps

Hall, J., Dore, A., J., Heywood, E., Broughton, R., Stedman, J., Smith, R. I., Hanlon, S., O., 2006. Assessment of the environmental impacts associated with the UK Air Quality Strategy. Report to DEFRA. http://www.airquality.co.uk/archive/reports/

Hulme, M. and Barrow, E. M., 1997. Introducing climate change. pp.1-7 in: Climates of the British Isles: Present, Past and Future M. Hulme and E.M. Barrow, Eds., Routledge, London, pp. 454.

Inglis D. W. F., Choularton T. W., 2000. Fine scale spatial variations in wet deposition, Atmospheric Research 55, 149-157. 
Irwin J., Campbell G., Vincent K., 2002. Trends in sulphate and nitrate wet deposition over the United Kingdom: 1986-1999. Atmospheric Environment 36, 2867-2879.

Lamb, H.H., 1972. British Isles weather types and a register of daily sequence of circulation patterns, 1861-1971. Geophysical Memoir 116, HMSO, London, pp. 85.

Lee, D.S., R.D. Kingdom, Jenkin M., E., Garland J. A.,2000. Modelling the atmospheric oxidised and reduced nitrogen budgets for the UK with a Lagrangian multi-layer long-range transport model. Environmental modelling and assessment 5, 83-104.

Mayerhofer, P., Vries, B., Elzen, M., Vuuren, D., Onigkeit, J., Posch, M., Guardans, R., 2002. Longterm, consistent scenarios of emissions, deposition, and climate change in Europe. Environmental Science \& Policy 5, 273-305.

Metcalfe, S.E., Whyatt, J.D., Broughton, R., Derwent, R.G., Finnegan, D., Hall, J., Mineter, M., O'Donoghue, M. and Sutton, M.A., 2001. Developing the Hull Acid Rain Model: its validation and implications for policy makers. Journal of Environmental Science and Policy 4, 25-37.

Mill, W.A., Schlama, A., Twarowski, R., Błachuta J., Stasyewski, T., 2003. Modelling and Mapping of Critical Thresholds in Europe. CCE Status Report 2003. National Focal Centre Report Poland, Bilthoven, Netherlands.

Mitosek, G., Degórska, A., Iwanek, J., Przybylska, G., Skotak, K., 2004. EMEP Assessment Report Poland. Institute of Environmental Protection, Warsaw.

NECD, 2007. Reporting by the Member States under Directive 2001/81/EC of the European Parliament and of the Council of 23 October 2001 on national emission ceilings of certain atmospheric pollutants, EEA, Copenhagen.

NEGTAP, 2001. Transboundary Air Pollution: Acidification, Eutrophication and Ground Level ozone in the UK. Report of the National Expert Group on Transboundary Air Pollution. DEFRA, London.

Posch, M., Hettelingh, J.P., de Smet, P.A.M., Downing, R.J., 1997. Calculation and mapping of critical threshold in Europe: Status Report 1997. RIVM Report No. 259101007. Coordination Centre for Effects, Bilthoven, Netherlands.

Singles, R.J., M.A. Sutton \& K.J. Weston, 1998. A multi-layer model to describe the atmospheric transport and deposition of ammonia in Great Britain. Atmospheric .Environment 32, 393-399.

Smith R.I., Fowler D., Sutton M.A., Flechard C. and Coyle M., 2000. Regional estimation of pollutant gas deposition in the UK: model description, sensitivity analyses and outputs. Atmospheric Environment 34, 3757-3777.

Smith, R.I. and Fowler, D., 2001. Uncertainty in wet deposition of sulphur Water, Air and Soil Pollution: Focus 1: 341-354.

Vieno, M., 2005. The use of an Atmospheric Chemistry-Transport Model FRAME over the UK and the development of its numerical and physical schemes. $\mathrm{PhD}$ thesis, University of Edinburgh.

Vuorenmaa, J., 2004. Long-term changes of acidifying deposition in Finland 1973-2000. Environmental Pollution 128, 351-362.

www.cru.uea.ac.uk/cru/data/lwt.htm

Yu, S., Eder, B., Dennis, R., Chu, S.H., Schwartz, E., 2006. New unbiased symmetric metrics for evaluation of air quality models. Atmospheric Science Letters 7, 26-34. 